Gut, 1972, 13, 775-783

\title{
Functional and morphological response of the dog colon to ischaemia
}

\author{
J. W. L. ROBINSON, C. RAUSIS, P. BASSET, AND V. MIRKOVITCH
}

From the Département de Chirurgie Expérimentale, Services Universitaires de Chirurgie et d'Anatomie Pathologique, Hôpital Cantonal Universitaire, Lausanne

SUMmaRY Total ischaemia of loops of dog colon was induced by clamping all afferent arteries and the colonic wall for different periods of time.

Net sodium transport across the mucosa is abolished after one hour's ischaemia, but $\mathrm{Na}^{+}-\mathrm{K}^{+}$ ATPase levels in microsomal suspensions from the mucosa only fall significantly after two hours' ischaemia.

Studies on the functional and morphological recovery of colons subjected to three hours' ischaemia have disclosed an extremely heterogeneous response among the 24 dogs used. Although all parameters were non-existent 24 hours after the intervention, one colon revealed a morphological and functional recovery one week after the operation, whilst two, three, and three out of six recovered after two, three, and four weeks respectively. There was a good correlation between the functional and macroscopic appearance of these recovered loops, though histologically various degrees of disorganization of the mucosa were observed. Among the loops that had no function, there was also a considerable variation in their microscopic structures.

The level of $\mathrm{Na}^{+}-\mathrm{K}^{+}-\mathrm{ATPase}$ in the mucosa was found to be a faithful indicator of the functional state of the tissue, and could be closely correlated with the morphological findings.

The colonic mucosa is considerably less sensitive to ischaemia than the mucosa of the small intestine (Rausis and Robinson, 1972), but nevertheless the response of the colon to ischaemia has been the subject of several experimental studies in recent years, chiefly on account of the clinical interest of an investigation of this nature. Thus Boley, Schwartz, Lash, and Sternhill (1963), Boley, Krieger, Schultz, Robinson, Siew, Allen, and Schwartz (1965), de Villiers (1966) and Marston, Marcuson, Chapman, and Arthur (1969) have all studied the effects of devascularization of the large intestine, using different experimental models, and have attempted to correlate their findings with clinical experience. These authors have, however, generally presented only morphological and radiological data, although Marston et al (1969) did include serum enzyme determinations and leucocyte counts in their work. The present study was undertaken to obtain functional data on the dog colon subjected to acute ischaemia of different durations, and at various stages

Received for publication 18 July 1972. of recovery after an ischaemia of three hours. Besides the functional tests, macroscopic, microscopic, and microcirculatory data were obtained at the moment of excision of the colon, and barium enemas were performed at different times during the recovery phase. This paper presents the functional data, and briefly records the salient points of the morphological examinations to provide the relevant correlations between the different investigations. The histological study will be presented in detail elsewhere (Basset, 1972), and the correlations with clinical data are the subject of separate publications (Rausis, Robinson, Mirkovitch, and Saegesser, 1972a, b).

\section{Methods}

SURGICAL

Complete ischaemia was induced in a loop of dog colon by clamping all afferent vessels and the colonic wall for a specific period of time. The technical details are given elsewhere (Rausis et al, 1972a, b). In the first series of experiments ('acute experiments'), the colon was divided into four successive loops, 
which were subjected to different periods of ischaemia (control, one hour, two hours, and three hours). The loops were rotated in different dogs to eliminate regional bias. Each loop was removed for examination immediately after completion of its appropriate period of ischaemia. In the second series ('recovery experiments'), the clamps were removed from the loop after threa hours' ischaemia, the serosal aspect of the tissue was recorded, and the abdomen was closed. Barium enemas were performed at suitable intervals after the intervention. After one day, or one, two, three, or four weeks the animal was re-opened and the ischaemic loop, together with a neighbouring control, was removed for examination.

\section{FUNCTIONAL STUDIES}

The principal function of the colonic mucosa, namely, its ability to transport sodium ions, was determined by measuring the flux of ${ }^{22} \mathrm{Na}$ across specimens of isolated mucosa clamped in plexiglass flux chambers. The mucosa is stripped from the muscle by simple dissection, and is mounted between two hemichambers. The medium bathing each surface consists of Krebs bicarbonate buffer containing $0.2 \%(w / v)$ glucose, and a tracer dose of ${ }^{22} \mathrm{Na}$ is added to one side of the tissue. The solutions are maintained at $37^{\circ} \mathrm{C}$ in a thermostatically controlled water jacket, and continuous passage of $95 \% / 5 \%$ oxygen $/ \mathrm{CO}_{2}$ not only maintains the oxygenation and $p \mathrm{H}$ of the buffer, but also ensures mixing of the contents in the chambers. Six parallel chambers were used whenever possible, three for the determination of the mucosal-serosal flux, and three for the serosal-mucosal flux. Samples were taken at 10-minute intervals from the fluid which initially contained no isotope, and the flux was calculated over the 20 - to 60 -minute period (when steady flux occurred). The difference between the two mean fluxes represents the net sodium flux.

In addition to the flux measurements, the levels of $\mathrm{Na}^{+}-\mathrm{K}^{+}$-ATPase, an enzyme closely linked with ion transport, and residual ATPase in microsomal fractions of mucosal homogenates were determined. The mucosa was homogenized in an Ultraturrax homogenizer in a mixture of $80 \% 0.3 \mathrm{M}$ saccharose

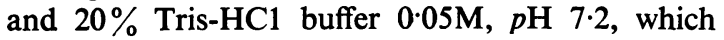
also contained $1 \mathrm{mM}$ EDTA and $0.2 \%$ deoxycholate (Tris salt). The homogenate was centrifuged at $5000 \mathrm{~g}$ and the pellet was re-homogenized and recentrifuged at the same speed. The two supernatants were then mixed and centrifuged at $75000 \mathrm{~g}$ to provide a microsomal fraction. This pellet was suspended in the same saccharose/Tris/EDTA/DOC mixture as was used for the original homogenization. The ATPase activity was assayed by incubation of aliquots of suspension for 10 minutes in the presence of $100 \mathrm{mM}$ imidazole buffer $(p \mathrm{H} \mathrm{7 \cdot 2}), 5 \mathrm{mM} \mathrm{MgCl}$, $100 \mathrm{mM} \mathrm{NaCl}, 10 \mathrm{mM} \mathrm{KCl}$, and $2 \mathrm{mM} \mathrm{Na}_{2} \mathrm{ATP} ; 0 \cdot 4$ $\mathrm{mM}$ ouabain was added to some of the tubes to inhibit the $\mathrm{Na}^{+}-\mathrm{K}^{+}$-ATPase. The phosphate liberated during the incubation was determined by the method of King (1932) and the protein concentration of the original suspension by the method of Lowry, Rosebrough, Farr, and Randall (1951). In the absence of ouabain, the total ATPase is measured, whereas in the presence of the inhibitor, only the residual ATPase activity can be determined. Thus the difference between the two values provides a measure of the $\mathrm{Na}^{+}-\mathrm{K}^{+}$-ATPase activity.

\section{MORPHOLOGICAL STUDIES}

For histology, samples were stained with haematoxylin/eosin, PAS, alcian blue, prussian blue, elastin, and Van Gieson's stain. The microcirculation was visualized by injection of indian ink into the arteries, after which the tissue was fixed in formol, and either discoloured with methyl benzoate, or stained with haematoxylin/eosin (Rausis et al, 1972a). The ischaemic loops were always compared with a control from the same animal.

\section{STATISTICAL METHODS}

The 'acute experiment' was designed as a $4 \times 4 \times 4$ Latin square, four dogs providing four colonic loops, each of which was subjected to a different experimental condition. By rotating the loops, each level of the colon was used once for each condition. The analysis of variance of the results obtained for this experiment provided values of ' $D$ ', the least significant difference at a given significance level (designated as $D_{0.05}, D_{0.05}$, etc, in the tables), so that the means for each condition could be compared with each other (Pearce, 1965).

The analysis of the 'recovery experiments' was always performed with paired tissues, ie, an adjacent control tissue was tested in parallel with the pathological loop. Their results were evaluated by classical analyses of variance, as will be described with the experiments in question.

\section{Results}

\section{ACUTE EXPERIMENTS}

\section{Morphology}

After one hour of ischaemia, remarkably little damage to the colonic mucosa can be observed under the light microscope, with the exception, perhaps, of slight evidence of desquamation of the epithelial cells. The microcirculation appears quite intact. This finding is in stark contrast to the tremendous autolytic damage occurring in the ileum 


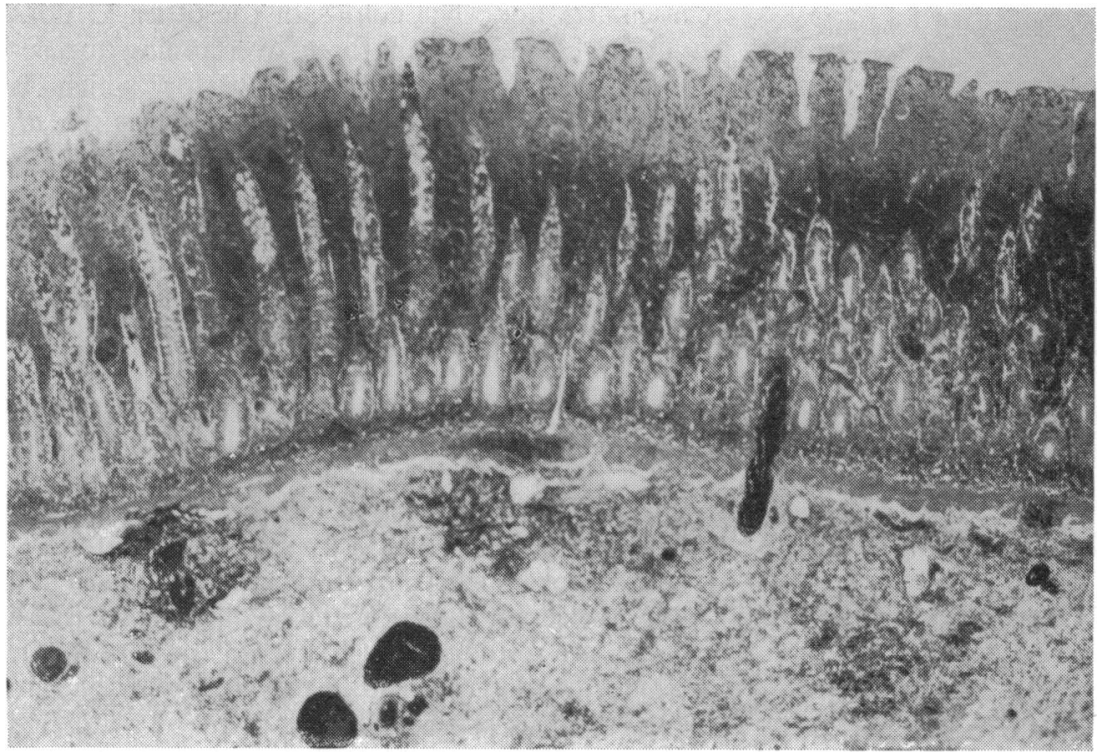

Fig. 1 Dog colon immediately after three hours' ischaemia. Capillary network injected with indian ink and sample stained with haematoxylin and eosin $(\times 45)$. of the rat after only 30 minutes' ischaemia (Robinson, Antonioli, and Mirkovitch, 1966) or in the dog ileum after one hour's ischaemia in the presence in the lumen of a protective glucose-containing buffered solution (Robinson, Mirkovitch, and Rausis, 1972).

A more severe cellular desquamation is observed after an ischaemic period of two hours, and this is accompanied by a marked thinning of the colonic wall. The microcirculatory studies indicated that some venules were blocked at this stage.

After three hours (Fig. 1) the mucosa is the site of a heavy haemorrhagic infiltration, and the microperfusion is completely obstructed. A marked oedema of the submucosa is observed and the submucosal venules are occluded. The microcirculation of the muscular layers, as well as their overall structure, remains intact. These findings agree well with the observations on human tissue reported by Morson (1970).

\section{Functional studies}

The normal colonic mucosa is the site of a relatively high $\mathrm{Na}^{+}-\mathrm{K}^{+}$-ATPase activity (Table I). This value is progressively reduced as the acute ischaemic period is prolonged, but the diminution after one hour's ischaemia is not statistically significant. There is also a small reduction in the levels of the residual ATPase occurring concomitantly. Despite the large reduction in $\mathrm{Na}^{+}-\mathrm{K}^{+}$-ATPase, $29 \%$ of the original activity nevertheless remains after three hours' ischaemia, whereas many colons in the 'recovery' group had no finite levels of the enzyme. This indicates that even if the cells are ruptured, the

\begin{tabular}{|c|c|c|c|}
\hline \multicolumn{2}{|l|}{ Period of Ischaemia (hr) } & $\mathrm{Na}^{+}-\mathrm{K}^{+}-\mathrm{ATPa}$ P & Residual ATPase \\
\hline & 207 & 82 \\
\hline \multirow{5}{*}{$\begin{array}{l}\text { Controls } \\
\text { One } \\
\text { Two } \\
\text { Three }\end{array}$} & & 154 & 82 \\
\hline & & 93 & 64 \\
\hline & & 60 & 49 \\
\hline & $D_{0.05}$ & 73 & 32 \\
\hline & $D_{0.01}$ & 110. & 49 \\
\hline
\end{tabular}

Table I ATPase activities in mucosal homogenates of colons subjected to different periods of ischaemia ${ }^{1}$

${ }^{1}$ ATPase levels, expressed in n-moles of phosphate liberated per min per $\mathrm{mg}$ protein, are the means of four values. The experiment was organized as a $4 \times 4 \times 4$ Latin square, with four dogs, four conditions, and four levels within the colon. The values of $D$ refer to the least significant differences between any two means at the given probability level.

breakdown of enzyme molecules is a relatively slower process.

Table II presents the transport studies on colons subjected to acute ischaemia. Two salient points emerge from Table II. First, the passive permeability of the mucosa (as determined by the serosal-mucosal flux of sodium) increases with prolongation of the ischaemic period; this would indeed have been suspected from the macroscopic condition of the tissue which, after long deprivation of the blood supply, became decidedly thin. Secondly, after one hour's ischaemia, all net active sodium transport has been abolished. This is in contrast to the ATPase findings, and suggests that despite the apparent histological integrity of the tissue, and the relatively intact enzyme levels, there are discrete lesions in the membrane at this stage which prevent it from functioning properly. A similar temporal 


\begin{tabular}{|c|c|c|c|c|}
\hline $\begin{array}{l}\text { Period of } \\
\text { Ischaemia (hr) }\end{array}$ & & $\begin{array}{l}\text { Mucosa- } \\
\text { Serosa }\end{array}$ & $\begin{array}{l}\text { Serosa- } \\
\text { Mucosa }\end{array}$ & Net Flux \\
\hline \multirow[t]{2}{*}{$\begin{array}{l}\text { Controls } \\
\text { One } \\
\text { Two } \\
\text { Three }\end{array}$} & & $\begin{array}{r}10 \cdot 27 \\
7.85 \\
14.81 \\
19 \cdot 37\end{array}$ & $\begin{array}{r}3.25 \\
6.73 \\
13.53 \\
20.05\end{array}$ & $\begin{array}{r}7.02 \\
1.12 \\
1.15 \\
-0.65\end{array}$ \\
\hline & $\begin{array}{l}D_{0.05} \\
D_{0.01}\end{array}$ & $\begin{array}{l}3.38 \\
5 \cdot 11\end{array}$ & $\begin{array}{l}5.66 \\
8.85\end{array}$ & $\begin{array}{l}4 \cdot 15 \\
6 \cdot 29\end{array}$ \\
\hline
\end{tabular}

Table II Sodium transport across mucosae from colons subjected to different periods of acute ischaemia ${ }^{1}$

${ }^{1}$ Values, which are expressed in $\mu$ equiv $/ \mathrm{hr} / \mathrm{cm}^{2}$, are the means of four dogs. The values of $\mathrm{D}$ were, as in Table I, obtained from a Latin square analysis of variance.

dissociation of the loss of $\mathrm{Na}^{+}-\mathrm{K}^{+}$-ATPase activity and transport capacity has been observed in small intestines subjected to acute ischaemia (Robinson et al, 1972).

\section{RECOVERY EXPERIMENTS}

\section{Macroscopic observations}

Just before the release of the vascular clamps following three hours' ischaemia the colon has a blue tinge and is obviously suffering from vascular stasis. Immediately after releasing the clamps the serosal face of the tissue takes on a rose colour, which is soon followed by the appearance of droplets of moisture on the serosal surface. After three hours' ischaemia the muscle is atonic. There are no other signs, from observation of the external aspect of the organ alone, at this stage or within the next few days, that the colon has undergone any trauma.

One day after ischaemia the mucosa is purple, greatly thickened, haemorrhagic, oedematous, and has the 'cobblestone' appearance described by Morson (1971); it is strikingly different from samples taken immediately after the end of the ischaemic period.

Thirty dogs were used to study the evolution of the colonic lesions one to four weeks following three hours' ischaemia of a loop. Four died of perforation of the colon (in the region of the clamps) during the first week after operation, one of postoperative haemorrhage, and one of invagination at three weeks. Of the 24 remaining, nine revealed an apparently normal mucosal layer (one after one week, two after two weeks, three after three weeks, and three after four weeks). There is no significant increase in the probability of recovery on extending the postoperative period $\left(\chi_{2}=1.96\right.$ with 3 degrees of freedom). In physiological terms, this indicates that the 'decision' as to whether the mucosa is going to recover or whether it is to evolve towards stenosis of the bowel is taken early after the revascularization. The colons of the other 15 dogs could be classified into three overlapping macroscopic states, the documentation for which is presented in another publication (Rausis et al, 1972b). Some dogs in the earlier stages after the operation revealed various degrees of haemorrhagic ulceration, sometimes accompanied by perforation (particularly in the region that had been clamped). Small areas of ulceration, as described by Marston et al (1969), who used less drastic experimental conditions, were never observed. A second condition consisted of the presence of a much thickened muscular layer, which had no apparent mucosal covering, but where there was no reduction in the circumference of the colon. Stenosis of the colon with a definite reduction in the bowel circumference probably developed from this, and was considered to be the final stage in the evolution of tissue necrosis as a result of this treatment. The appearance of stenosis could be readily followed with barium enemas (Rausis et al, 1972b).

\section{Histology}

One day after an ischaemia of three hours, the histological picture is one of widespread destruction (Fig. 2), the entire mucosa being replaced by a

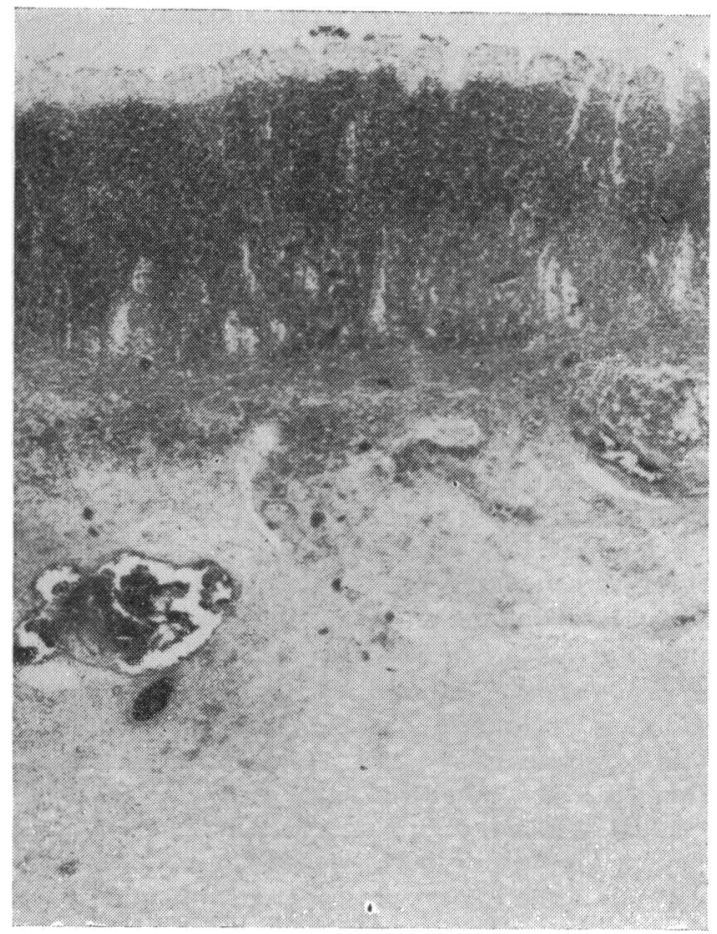

Fig. 2 Dog colon 24 hours after a period of three hours' ischaemia $(\times 45)$. 
haemorrhagic exudate containing heavy polynuclear infiltration, though one dog out of six was clearly less affected. The muscularis mucosae cannot be observed, and the submucosa was oedematous and heavily infiltrated. The muscular layers were also damaged in most cases, though the degree varied from one animal to another.

The specimens obtained one to four weeks after three hours' ischaemia can, as we have seen, be roughly grouped into colons that have recovered their mucosa, and those that have not. The five colons that had not recovered after one week provided a fairly homogeneous histological picture: the mucosal layer was replaced by an exudate composed of fibrin and polynuclear cells. The submucosa was also destroyed and replaced by inflammatory granulation tissue with fibroblastic proliferation. The muscular layers often displayed necrotic zones. Free iron was often seen in the muscular and submucosal layers, and particularly in the serosa. Similar pictures were seen in two dogs after two weeks, in two after three weeks, and in two after four weeks.

In another series of dogs, macroscopically classified as 'non-recuperated' (two after two weeks, one after three weeks, and one after four weeks), the histological picture was less drastic. The muscular

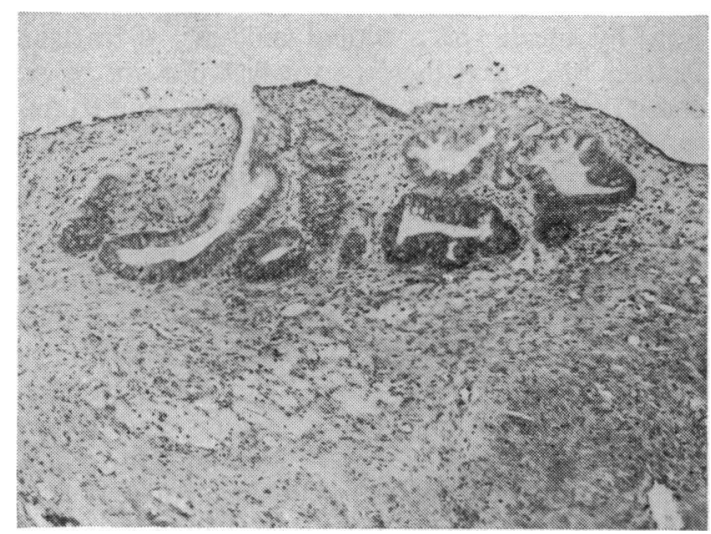

Fig. 3

Fig. 3 Islet of regenerated mucosa surrounded by granulation tissue in a colon three weeks after a period of three hours' ischaemia. This specimen was macroscopically classified as 'non-recuperated' $(\times 65)$.

Fig. 4 Example of highly disorganized mucosa with microcirculation visualized with Indian ink in a 'recuperated' specimen one week after three hours' ischaemia $(\times 110)$. layer was relatively intact, the submucosa consisted of granulation tissue, but on the surface, islets of well differentiated mucosa were observed, surrounded by atrophic tissue (Fig. 3). These islets often reposed on muscularis mucosae, although this was only present beneath the islets themselves.

There was apparently no correlation between the macroscopic presence of stenosis and the absence of islets on histological examination. Some animals classified as stenotic also revealed mucosal islets. This evidence is not, of course, conclusive, since the presence of islets might depend upon the region within the pathological loop from which the histological section was cut. Finally, the presence of islets does not provide unequivocal evidence in favour of discrete zones of regeneration surrounded by bare tissue, since the observations could be the result of a histological artefact and represent fingers protruding from the edge of intact tissue.

Amongst the 'recuperated' samples, there was also a considerable variation in the structure of the regenerated mucosa. The sole representative of this class in the one-week group revealed a mucosal surface punctuated by erosions, and a muscularis mucosae which was occasionally interrupted, particularly in zones where the mucosa was highly disorganized. Figure 4 shows a sample with a

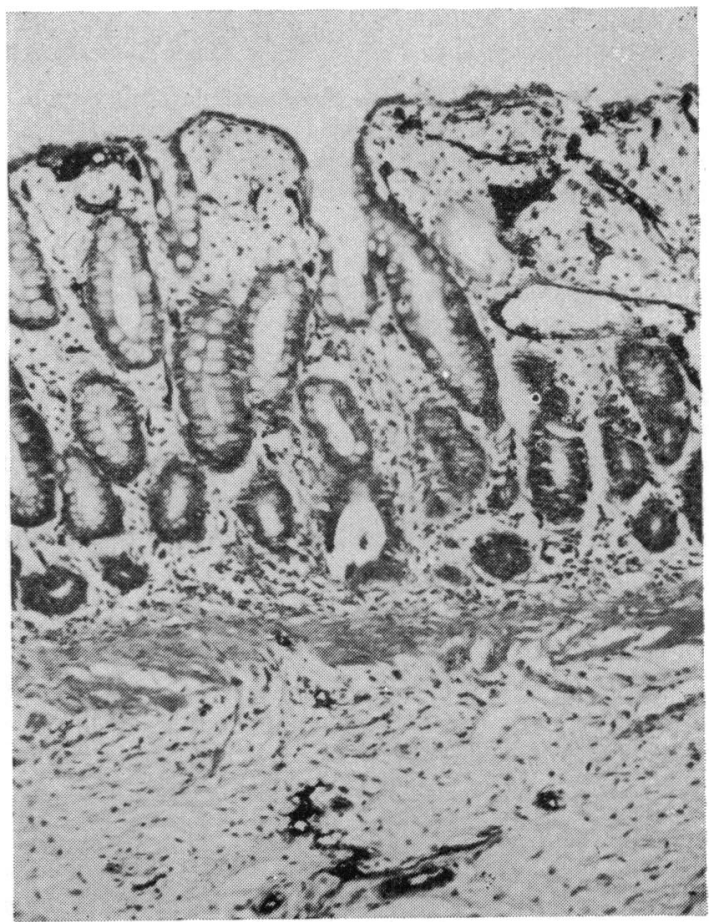

Fig. 4 


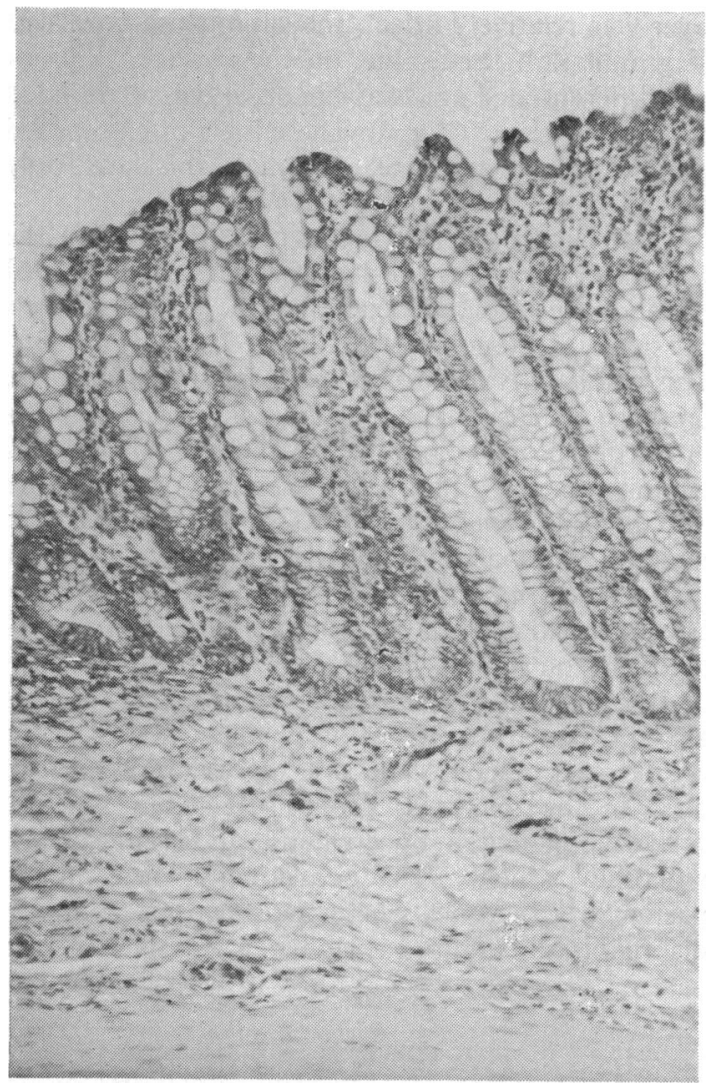

Fig. 5. Regenerated mucosa three weeks after a period of three hours' ischaemia. Note the lack of muscularis mucosae in this specimen, which had macroscopically and functionally 'recuperated' $(\times 110)$.

particularly irregular mucosal pattern. Free iron was still found in macrophages in the serosa, the muscular layer, and the submucosa. The two specimens in the two-week group displayed almost normal mucosae, though there were regions that were relatively disorganized. This was also true of the three colons of the three-week group, but in this series there was one specimen (Fig. 5) possessing an almost normal mucosa in the complete absence of a muscularis mucosae, the mucosa resting directly on the submucosa. This phenomenon is in opposition to the general observation that there was usually a good correlation between the state of the muscularis mucosae and that of the epithelial cells, though the muscularis mucosae was often broken in cases of mucosal disorganization.

\section{Functional studies}

The three animals studied 24 hours after the threehour ischaemia provided a homogeneous population, in which mucosal ATPase activities and net sodium transport were zero (Table III). Note that the $\mathrm{Na}^{+}-\mathrm{K}^{+}$-ATPase activity is now absent, whereas at the end of the three-hour ischaemic period there was still a finite level of the enzyme in the mucosa. The morphological results confirm that the degree of necrosis is indeed much greater at this stage than at the end of the ischaemia.

The levels of $\mathrm{Na}^{+}-\mathrm{K}^{+}$-ATPase appeared to be a faithful indicator of the functional state of the tissue, as shown in Figure 6. The columns present the mean values of the control loops of the dogs in question, whereas the circles correspond to the values obtained for the ischaemic loops that, according to macroscopic criteria, had recovered, and the crosses to those that had not. Two control values in the three-week group were absurdly low, and it was possible to show by means of a global analysis of variance (Pearce, 1965) that these two values did not belong to the control population $\left(F_{2 \cdot 19}=9 \cdot 4\right)$, and so they were discarded from consideration. The other 22 values provided a homogeneous population with a mean activity of $253 \pm 115( \pm 2$ SD); hence all values below 138 can be safely considered to be outside the control limits. This applies to five dogs in the one-week group, four dogs in the two-week group, three dogs in the four-week group, and all dogs in the three-week group. However, unfortunately, two of the dogs whose colons had macroscopically recuperated after three weeks, corresponded with the two aberrant controls, so it is reasonable to suppose that their values were not

\begin{tabular}{|c|c|c|}
\hline & Control Loop & Pathological Loop \\
\hline $\begin{array}{l}\mathrm{Na}^{+}-\mathrm{K}^{+}-\mathrm{ATPase} \\
\text { Residual ATPase } \\
\text { (n-moles phosphate/min/mg protein) }\end{array}$ & $\begin{array}{l}126 \pm 20 \\
163 \pm 14\end{array}$ & $\begin{array}{r}8.3 \pm 6.8 \\
18 \pm 5.6\end{array}$ \\
\hline $\begin{array}{l}\text { Mucosal-serosal sodium flux } \\
\text { Serosal-mucosal sodium flux } \\
\text { Net sodium flux ( } \mu \text { equiv } / \mathrm{hr} / \mathrm{cm}^{2} \text { ) }\end{array}$ & $\begin{array}{r}10.59 \pm 1.65 \\
4.29 \pm 0.08 \\
6.30 \pm 1.67\end{array}$ & $\begin{array}{r}4.57 \pm 0.27 \\
4.87 \pm 0.24 \\
-0.30 \pm 0.46\end{array}$ \\
\hline
\end{tabular}

Table III ATPase activity and sodium transport in the mucosa of colons 24 hours after an ischaemia of three hours 1

${ }^{1}$ The results are the means of three identical experiments. 

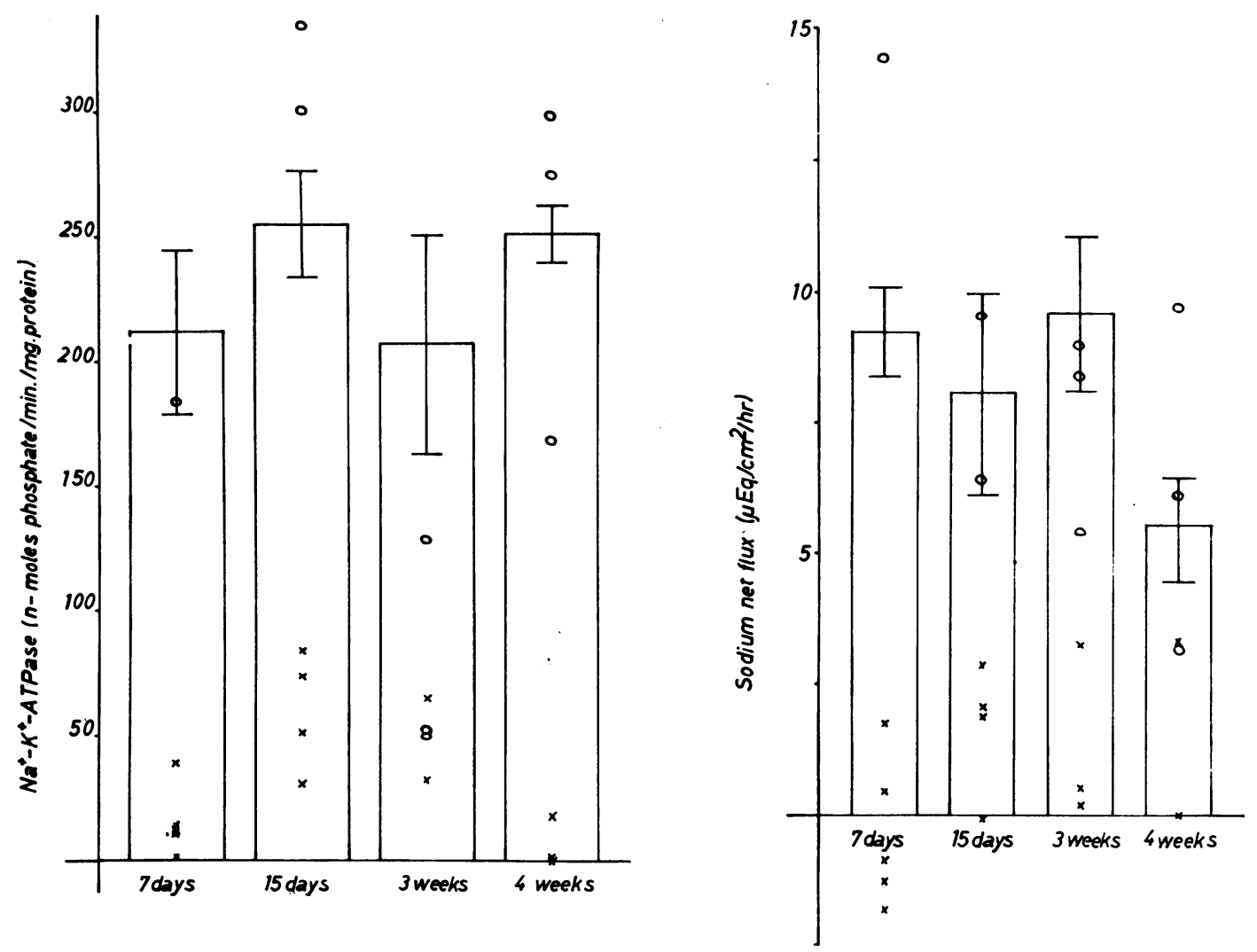

Fig. 6 Levels of $\mathrm{Na}^{+}-\mathrm{K}^{+}-$ATPase at different periods following three hours' ischaemia. The columns represent the means of the control loops, the circles the values of the 'recuperated' colons, and the crosses those of the 'nonrecuperated' colons (according to macroscopic criteria). Statistical analyses in text.

Fig. 7 Net sodium flux across isolated sections of colonic mucosa at different periods following three hours' acute ischaemia. Symbols as in Figure 1.

correct. As for the third 'recuperated' loop in the three-week group, its $\mathrm{Na}^{+}-\mathrm{K}^{+}$-ATPase level was only marginally outside the normal range, but this case may genuinely represent a 'semi-recuperation'. Histologically, it had a particularly disorganized mucosal layer.

The corresponding values for the net sodium flux across these colons are shown in Figure 7. Although there is generally a good agreement with other parameters, the results are not so well-defined in the case of transport as in the case of the enzyme studies. One reason for this is that some ischaemic loops were so contracted, that they did not provide enough tissue for the enzyme determinations, and for six flux chambers, with the result that just one unidirectional flux was measured, and the apparent net flux hinged on obtaining two identical tissue samples for the two flux measurements, which was obviously impossible. Nevertheless, seven dogs had evidently viable mucosae, the 'semi-recuperated' mucosa referred to above, fell in the middle of the column for three-week 1ecovery, and only one value in the four-week group appears not to agree with the other data. Statistically, the control group had a net flux of 8.13 \pm 7.58 ( \pm 2 SD), which means that some non-viable mucosae apparently had significant transport-but this can readily be attributed to the lack of sufficient tissue for adequate determinations.

\section{Discussion}

The study of sodium transport across the colonic mucosa in vitro has been restricted to relatively few investigations, and only two groups, to our knowledge, have undertaken such a study in pathophysiological states. Archampong, Harris, and 
Clark (1972) have recently measured sodium flux across normal human colonic mucosa, and have compared this with fluxes observed in inflammatory disease. Scharrer, Lutz, and Boehncke (1971) have examined the effect of various dietary influences on the transport of sodium across everted sacs of rat colon, a preparation generally used for small intestinal transport studies. In the present work, the determination of net sodium flux using tracer techniques was found to be a relatively reliable parameter, provided sufficient tissue was available for an adequate number of parallel determinations. In many pathological cases, particularly those displaying no morphological recovery, this condition was not fulfilled, and considerable dispersion was encountered.

On the other hand, the level of $\mathrm{Na}^{+}-\mathrm{K}^{+}$-ATPase, an enzyme known to be associated with sodium transport in many tissues (Skou, 1965), appears to be a faithful indicator of the functional state of the tissue. To our knowledge, this enzyme has not been investigated in the colonic mucosa previously, and almost certainly not employed as a determinant for its functional viability. The present study reveals its suitability and raises the possibility of its use as a clinical test for this purpose. Sufficient tissue should be obtainable from rectal biopsy to enable the level of this enzyme in the mucosa to be determined in vitro.

Previous experimental work on the response of the large intestine to ischaemia has concentrated mainly on the anatomo-pathological changes in the ischaemic gut (Marston et al, 1969; de Villiers, 1966) and on the correlations between experimental observations and clinical experience. We have also noted a close correlation between our findings and observations on ischaemic colitis, as reported elsewhere (Rausis et al, 1972a, b), but unfortunately we have not yet had the opportunity to study human ischaemic colons from the functional viewpoint. The loss of transport capacity of human colons as a function of the period between excision and study has been discussed by Grady, Duhamel, and Moore (1970) and represents a real obstacle to the realization of a project of this nature. By studying ATPase levels, this difficulty should be overcome.

Although the colon is apparently less sensitive to the effects of acute ischaemia than the small intestine, it appears that three hours' total deprivation of blood represents the ultimate limit from which some organs can recover. Two principal outstanding questions remain unanswered after the completion of the present study. First, why should there be such an enormous variation in the ability of the colon to recover from three hours' ischaemia? The age and body weight of the dogs probably played a certain role, and the length of the ischaemic loop could have been of importance (though attempts at finding a correlation between these factors were unsuccessful). More likely is the role played by the intensity of the revascularization: three houls' clamping of a major vessel is bound to provoke certain lesions in the vascular wall, and although the presence of pulsations following the release of the clamps was confirmed in each case, it was impossible to ensure that in all cases an unobstructed blood supply persisted during the recovery period. Such differences in the level of revascularization could have led to the variations in recovery observed.

The second question concerns the manner in which the recovery occurs. An attempt to answer this in the light of the results presented is particularly unrewarding. The progression towards stenosis appears relatively uncomplicated in the cases that reach that stage, but even some stenotic colons displayed islets of regeneration in the histological images, though it is difficult to believe that these specimens would ever regain a normal mucosa. No evidence was obtained, however, to indicate from what stage the mucosa could be regenerated. Since the macroscopic picture at later stages was always one of recovery or complete atrophy, the possibility must be considered that the regeneration of the mucosa is a relatively sudden process. On the other hand, Morson $(1970,1971)$ has described stenotic tissue in the human colon which reveals areas of ulceration, ie, denuded tissue, surrounded by irregular mucosal covering. If his observations are applicable to dog tissue, this would indicate that recovery (partial or total) of the mucosa would eventually occur, even in cases with stenotic bowels.

This study was supported by a grant from Schering International Inc. We are grateful to our colleagues Drs A. Fischer and J. Borgeaud for helping with the operations, to Monsieur F. Ganguillet for the construction of the flux chambers, and to our assistants Mmes J. Brero, L. Kohli, and Z. Simićević, and Mlles C. Brandt, D. Gasper, U. Päßler, and J. Vouron for the technical work involved.

\section{References}

Archampong, E. Q., Harris, J., and Clark, C. G. (1972). Water and electrolyte transfer by colonic mucosa studied in vitro. Brit. J. Surg., 59, 314.

Basset, P. (1972). Etude histologique d'une ischémie colique expérimentale. MD Thesis, Faculty of Medicine, Lausanne University.

Boley, S. J., Krieger, H., Schultz, L., Robinson, K., Siew, F. P., Allen, A. C., and Schwartz, S. (1965). Experimental aspects of peripheral vascular occlusion of the intestine. Surg. Gynec. Obstet., 121, 789-794.

Boley, S. J., Schwartz, S., Lash, J., and Sternhill, V. (1963). Reversible vascular occlusion of the colon. Surg. Gynec. Obstet., 116, 53-60. 
Grady, G. F., Duhamel, R. C., and Moore, E. W. (1970). Active transport of sodium by human colon in vitro. Gastroenterology, 59, 583-588.

King, E. J. (1932). The colorimetric determination of phosphorus. Biochem. J., 26, 292-297.

Lowry, O. H., Rosebrough, N. J., Farr, A. L., and Randall, R. J. (1951). Protein measurement with the Folin phenol reagent. J. biol. Chem., 193, 265-275.

Marston, A., Marcuson, R. W., Chapman, M., and Arthur, J. F. (1969). Experimental study of devascularization of the colon. Gut, 10, 121-130.

Morson, B. C. (1970). Pathology of ischaemic colitis. Bibl. gastroent. (Basel), 9, 134-136.

Morson, B. C. (1971). Histopathology of intestinal ischaemia. In Vascular Disorders of the Intestine, edited by S. J. Boley, S. Schwartz, and L. F. Williams, pp. 103-121. Appleton-CenturyCrofts, New York.

Pearce, S. C. (1965). Biological Statistics: An Introduction. McGrawHill, New York.

Rausis, C., and Robinson, J. W. L. (1972). Sensibilité de la muqueuse intestinale à l'insuffisance circulatoire. Praxis, 61, 217-219.
Rausis, C., Robinson, J. W. L., Mirkovitch, V., and Saegesser, F. (1972a). Ischémie colique nécrosante et gangreneuse: faits cliniques et recherche expérimentale. Helv. chir. Acta, 39, 251258.

Rausis, C., Saegesser, F., Robinson, J. W. L., and Mirkovitch, V. (1972b). Désordres vasculaires du gros intestin: Données expérimentales et corrélation clinique. Helv. chir. Acta, in press.

Robinson, J. W. L., Antonioli, J. A., and Mirkovitch, V. (1966). The intestinal response to ischaemia. Naunyn-Schmiedeberg's Arch. Pharmak. exp. Path., 255, 178-191.

Robinson, J. W. L., Mirkovitch, V., and Rausis, C. (1972). Récupération fonctionnelle et morphologique de l'intestin grêle de chien après ischémie aiguë. Helv. chir. Acta, in press.

Scharrer, E., Lutz, J., and Boehncke, E. (1971). Ernährungsbedingte Veränderungen der intestinalen Natrium- und Wasserresorption. Ernährungs-Umschau, 6, 248-250.

Skou, J. C. (1965). Enzymatic basis for active transport of $\mathrm{Na}^{+}$and $\mathrm{K}^{+}$across cell membranes. Physiol. Rev., 45, 596-617.

de Villiers, D. R. (1966). Ischaemia of the colon: an experimental study. Brit. J. Surg., 53, 497-503. 